\begin{tabular}{|r|c|c|}
\hline \multicolumn{1}{|c|}{ Received: September 2017} & Accepted: January 2018 & Published: April 2018 \\
\hline \hline & Article DOI: $\underline{\text { http://dx.doi.org/10.24903/sj.v3i1.146 }}$ \\
\hline
\end{tabular}

\title{
Vocabulary Mastery by Using Storytelling
}

Sektalonir Oscarini Wati Bhakti

Samarinda State Polytechnic, East Kalimantan

sektalonir1226@gmail.com

Marwanto

Samarinda State Polytechnic, East Kalimantan marwantopolnes@gmail.com

\begin{abstract}
This research investigated 80 students of Diploma III Architecture of Samarinda State Polytechnic to see their vocabularies mastery trough storytelling. Telling the stories is one of the best way to find out the students' English Mastery. Some obstacles are also found in learning English trough performing storytelling in the class such as the suitable material and text for the students, the lack of ability of the students and the teacher in conducting story as well as the readiness and the nervousness of the storytellers. As an English lecturer, the researcher also finds that how to improve vocabularies is one of the students' problems in learning English. It is proved when the students are asked to tell a story in front of the class. In this research, the students needed telling stories before they had the English vocabulary test. From the test, it could be concluded that the highest score was 92 got by one (1) student while the lowest score was 46 got by one (1) student. Meanwhile, the average score was 78 that classified fair (B). There were two (2) students who got below 50 that classified Fail. The results show that even the students' English mastery were satisfied but the students still need to practice how to tell the story in a good way so that they will master in all aspects.
\end{abstract}

Keywords: Samarinda State Polytechnic, Students' Mastery, Storytelling 


\section{INTRODUCTION}

As English is one of subjects learnt in Indonesia, knowing some English vocabularies is an essential and fundamental condition. Without vocabularies, the learners of language will get lost and confused so that they will not be able to express their feeling and idea in speaking, reading, writing and also listening. Having English vocabularies, the learners can communicate with other people from abroad to get information whether from textbook, newspapers, magazines, internet websites, radio, or television. The advance developing technology also leads Indonesians to use English as an aid to access modern technology. Moreover, English is increasingly important in Indonesia because of the free and global trading.

Vocabularies can be planted to the students by several ways. One of them is by storytelling. According to defined storytelling as a knowledge management technique, a way of distributing information, targeted to audiences and a sense of information. The use of stories through storytelling is a valuable knowledge management practice because it is already so deeply a part of the general culture that is easy to adapt to knowledge management goals and objectives and "the significance of story and storytelling is apparent when one reviews the current body of published research," (Boyce in Volkerm John X.m Phillips, Michael D. \& Aderson, Steven J, (2011))

There are some models for the use of stories and storytelling have been identified. These can be used and selected as a model. Storytelling can be conducted by the teacher and the learners. The learners are asked to listen the stories told by a person or a teacher directly or from the video that the learners can increase their vocabularies as well as their ability in listening. Besides that, the teacher can also ask the learners to retell or rewrite about the story that they have just listened. The teacher can also ask the learners to present stories in front of the class so that the students can express their feeling as well as to learn how to pronounce the word well.

Some obstacles are also found in learning English trough performing storytelling in the class such as the suitable material and text for the students, the lack of ability of the students and the teacher in conducting story as well as the readiness and the nervousness of the storytellers. 
As an English lecturer in Civil Engineering Department of Samarinda State Polytechnic, the researcher also finds that how to improve vocabularies is one of the students' problems in learning English. It is proved when the students are asked to tell a story in front of the class. That is why the researcher would like to find out the Vocabulary mastery by using storytelling of the second semester students Civil Engineering Department of Samarinda State Polytechnic.

\section{The Importance of Vocabulary}

Zimmerman in Anisa (2016) states that vocabulary is central to language and critical importance to the typical language learning. Vocabulary should not be neglected by those who learn a language. It even needs to be mastered if someone wants to master the four language skills. Inadequate vocabulary obstruct students; development in learning English. Moreover, Blachowicz, Fisher, \& Watts-taffe (2005) emphasized that to affect reading performance, vocabulary knowledge affects a student's ability to participate fully in both social and academic classroom routines. In this regard, all students can benefit from vocabulary instruction, especially if that instruction is tailored to individual strengths and needs.

Thorndike and Lorge in Anisa (2016) classify types of vocabulary as follows:

\begin{tabular}{|c|c|c|c|c|}
\hline $\begin{array}{c}\text { Types of } \\
\text { Vocabulary }\end{array}$ & $\begin{array}{l}\text { Numbers of } \\
\text { words }\end{array}$ & frequently & $\begin{array}{c}\text { Coverage of } \\
\text { text }\end{array}$ & $\begin{array}{c}\text { Implications for } \\
\text { teaching and learning }\end{array}$ \\
\hline $\begin{array}{l}\text { High- } \\
\text { Frequency } \\
\text { words }\end{array}$ & 2,000 & Occur frequently & $\begin{array}{l}\text { About } 87 \% \text { of } \\
\text { the running } \\
\text { words in a text }\end{array}$ & $\begin{array}{l}\text { Spend a lot of time on } \\
\text { these words. Make sure } \\
\text { they are learned }\end{array}$ \\
\hline $\begin{array}{l}\text { Academic } \\
\text { vocabulary }\end{array}$ & 800 & $\begin{array}{l}\text { Occur frequently } \\
\text { in most kinds of } \\
\text { academic texts }\end{array}$ & $\begin{array}{l}\text { About } 8 \% \text { of the } \\
\text { running words } \\
\text { in academic } \\
\text { texts }\end{array}$ & $\begin{array}{l}\text { If learners are in upper } \\
\text { secondary school or in } \\
\text { tertiary education }\end{array}$ \\
\hline $\begin{array}{l}\text { Technical } \\
\text { Vocabulary }\end{array}$ & $\begin{array}{l}\text { About } 1,000 \text { to } \\
2,000 \text { for each } \\
\text { subject }\end{array}$ & $\begin{array}{l}\text { Occur, sometimes } \\
\text { frequently in } \\
\text { specialized texts }\end{array}$ & $\begin{array}{l}\text { About } 3 \% \text { of the } \\
\text { running words } \\
\text { in a specialized } \\
\text { texts }\end{array}$ & \\
\hline $\begin{array}{c}\text { Low- frequently } \\
\text { words }\end{array}$ & About 123,000 & $\begin{array}{l}\text { Do not occur very } \\
\text { frequently }\end{array}$ & $\begin{array}{l}\text { About } 2 \% \text { or } \\
\text { more of the } \\
\text { words in any } \\
\text { texts }\end{array}$ & \\
\hline
\end{tabular}

Table 1. The Vocabulary Classification

From the table above, it will help the teacher to decide which group should the learner be classified so that the teacher can figure out the number of words should the students have to know and learn. 
Ur in Nugroho (2012) stated that there are five aspects of vocabulary must the teacher and learners give their attention. They are as follow:

a. Form. The mastery of Vocabulary involves the mastery of pronunciation and spelling. The leaner has to know how the word is sounded and how the word is spelled. In teaching, the teacher needs to make sure that both these aspects are accurately presented and learned

b. Grammar. The grammar of a new word needs to be taught if this is mot obviously covered by general grammatical rules. A word may have an unpredictable change of form in certain grammatical contexts. It is important to provide learners with the information at the same time the teacher teaches the base form of a word.

c. Collocation. The collocation typical of particular items is another factor that makes a particular combination sound 'right' or 'wrong' in a given context. This is another piece of information about a new item which may be worth teaching. Collocation is also often noted in dictionaries, either by providing the whole collocation under one of the head-words, or by a note in parenthesis.

\section{d. Aspect of Meaning}

Denotation, Connotation, Appropriateness. Denotation is the meaning of a word that primarily refers to the real world. It is often the sort of definition in dictionary. Meanwhile, a less obvious component of the meaning of an item is its connotation, the associations, or positive or negative feelings it evokes, which may or may not be indicated in a dictionary definition.Besides denotation and connotation, an aspect of meaning that also needs to be taught is whether a particular item is appropriate one to use in a certain context or not. It is useful for a leaner to know that a certain word is very common, or relatively rare, or 'taboo' in polite conversation, or tends, to be used in writing but not in speech, or is more suitable for formal than informal situation, or belongs to a certain dialect.

Meaning Relations. How the meaning of one item relates to the meaning of others can also be useful in teaching. There are various such relationship, they are: synonyms (item that mean the same or nearly the same); antonyms (items that mean the opposite); hyponyms (item that serve as specific examples of a general concept); co-hyponyms or co-ordinates (other items that are the same kind of thing); superordinates (general concepts that cover specific items); and translation (words or 
expression in the learners' mother tongue that are equivalent in meaning to the item being taught)

e. Word Formation. Vocabulary items, whether one-word or multi-word, can often be broken down into their components exactly how these words are put together is another piece of useful information. Teachers may teach the common prefixes and suffixes. However, they should be warned that in may common words, the affixes no longer have any vocabulary items are built is by combining two words to make one item.

It could be concluded that vocabulary is the complete skill which from master some those vocabularies, the learners also learn how to pronounce, listen, and write correctly. The better they master the vocabulary, the better they speak and write in English. 


\section{Teaching Vocabulary}

In achieving four language skill, teaching vocabulary is one of the fundamental elements. Jordan in Anggriani (2012) states that teaching vocabulary is such an important task in teaching English because vocabulary achievement is related to all language learning and it is of concern to all four language skills

According to Wallace in Nilawati (2009) teaching vocabulary should consider these following factors:

\section{a. Aims.}

The aim of teaching vocabulary is to make the teacher easy to formulate the materials, which will be taught to the students.

\section{b. Quantity.}

The teacher has to decide the number of vocabulary items to be learned. The learners will get confuse or discouraged if they get many new words. Therefore, the teacher should select new words, which can easy to understand by the learners.

\section{c. Need.}

In teaching vocabulary, the teacher has to choose the words really needed by the students in communication.

\section{d. Frequent exposure and repetition.}

Frequent exposure and repetition here means that the teacher should give much practice on repetition so that the students master the target words well. They also give opportunity to the students to use words in writing or speaking.

\section{e. Meaningful presentation.}

In teaching vocabulary the teacher should present target words in such a way that the meaning of the target words are perfectly clear and unambiguous. 


\section{f. Situation and Presentation.}

The teachers tell the students that they have to use the words appropriately. The use of words depends on the situation in which they are used and depends on the person to whom they are speaking.

In teaching vocabulary, there are some techniques that can be applied in the class. Allen in Setiawan (2010) mentions some techniques of vocabulary teaching that can be prepared and chosen. They are as follows:

\section{a. Demonstration}

The technique, which belongs to demonstration, is gesture and action performing. The teacher can use real objects and command. Teacher may demonstrate the material using of real objects available in the classroom such as door, windows, clock, desk, etc. When use a command technique, teacher may ask students to do something such as touching the pen, pointing the picture and so on.

\section{b. Visual aids}

Visual means something visible. Teacher may use visual aids in the teaching of vocabulary to enable students to observe and identify the objects vividly. Besides that, visualization may interest the students in their learning vocabulary.

\section{c. Verbal Explanation}

Verbal explanation can be carried out through definition and translation. Teacher can use explanation in the students' own language, definitions in simple English, and using vocabulary that students have already known to show the meaning. For instance, the word 'umbrella' can be introduced by explaining what it looks like and when the people usually use it.

\section{d. Word List}

When using word list technique, teacher should pay attention to vocabulary selection. The words taught should relate and appropriate to the students need and relate to their level. 
From the information above, in teaching vocabulary, the teacher should consider about the suitable material and technique for the learner so that the aim of learning can be reached which is the learners can obtain the number of vocabularies required by the teacher.

\section{Storytelling}

According to Bishop and Glynn in Alterio (2003), storytelling is an ideal teaching and learning tool, for it takes seriously the need for students to make sense of experience, using their own culturally generated sense-making Storytelling also has the capacity to support and enhance the relationship between students creating new knowledge and learning from others. In addition, sharing and reflectively processing stories provides students with opportunities to develop authentic relationships with their peers.

Barzaq in Skhela (2010) defined storytelling as a knowledge management technique, a way of distributing information, targeted to audiences and a sense of information, she added that stories provide natural connection between events and concepts and finally, she added that visual storytelling is a way of telling stories through images. Moreover, Taylor (2013) defined storytelling as the act of an individual verbally recounting to one or more listeners, without the use of written text, a plausible account of an event or series of events.

In telling the story, the teacher should follow five sequential components so that the story will be effective in the process of learning. Morgan and Dennehy in Eck (2006) delivered those five sequential components:

a. The setting: a description of the time, place, characters and context so you provide something the audience can mentally image and feel a part of.

b. Build up: a sequence of events that warns the listener that something (usually some type of conflict) is about to happen. This creates suspense, interest and attention.

c. Crisis: the climax or high point of the story. This is also the place to introduce a new element and or a turning point.

d. Learning: point out what the central character(s) learned. Here lies the lesson of the story.

e. How change ensued in the character(s) behaviors, awareness, abilities: the storyteller focuses on the learning to be retained by the listener and is cautioned to not assume that 


\section{The Benefit of Storytelling}

There are some benefits that can be drawn from teaching through story telling. These benefits are resumed by Eck (2006) from many researcher who considered in teaching and learning storytelling.

1. Storytelling enhances the classroom environment and atmosphere. A good story can relax learners and reduce fears because they are entertaining and at times, humorous. A well told story can bring about a sense of community and belonging in learning communities better than most traditional teaching methods.

2. Storytelling engages students on a level that many teaching methods do not. Not only do learners hear the information, but they are immersed in the content on a deeper and richer level through emotional and personal connections and visual imagery. The fact that stories evoke emotions adds to their learning effectiveness because learning experiences associated with emotions are more easily stored and recalled.

3. Storytelling has many of the benefits of experiential learning due to the level of active engagement created. The vivid images stimulated by storytelling promote character identification thus engaging the student as an active participant in the learning process. When learners are engaged in this way, research reveals improved understanding and ability of the learner to apply what they have learned in the work setting.

\section{METHODOLOGY}

This chapter discusses overview of the design and method of the research. It describes the research design, population and sample, data collection procedures, data collection techniques, and data analysis.

\section{Research Design}

This research applied quantitative design that is about explaining phenomena by collecting quantitative data that are analyzed using mathematically based methods (Muijs, 2004)

\section{The Research Context}

This research was designed to describe the vocabulary mastery by using storytelling of Architecture students of Samarinda State Polytechnic, East Kalimantan. This research used 
quantitative method. All the participants was the second semester students of Architecture Study Program of Samarinda State Polytechnic.

\section{Population}

In this research, the researcher took all second semester Architecture Study Program students of Samarinda State Polytechnic as the population. The researcher found out that it was possible to give the test to all second Architecture Study Program students of Samarinda State Polytechnic as long as they were still in the same campus.

\section{Data Collection Techniques}

The instrument used in this study was a test that aimed to see the vocabulary mastery of the students

\section{Data Collection Procedures}

The researcher found out how many participants were her population of the research. The data of the participants was gotten from the Academic Department of Samarinda State Polytechnic that concerns about the students' data. After figuring out the number of the population, then the researcher constructed the test.

\section{Data Analysis}

Percentage of students passing the test was used to determine the participants' vocabulary mastery. They was classified that below 50 was in the problem area.

\section{FINDINGS AND DISCUSSION}

The data was gained from vocabulary test. The questions of the test was taken from TOEFL that consisted of 50 multiple questions. A week before the research conducted, the researcher had given two titles of storytelling that then chosen by the students randomly. There were 40 students told the first story "The Lantern Story. In this research, the researcher needed four days to ask the students to tell the stories. Therefore, there were 20 students told those stories each day.

In the fifth day, the students were given a vocabulary test. After giving the vocabulary test to the 80 students of Architecture study program, the researcher examined the answers and gave the score. Then, the score was tabulated in order to get the highest, the 
lowest, and average score. From the tabulation, the researcher would find out the percentage of the students who failed or passed the vocabulary test.

From Table 2, there were 80 students who followed the vocabulary test. It means that all students attended to the vocabulary test. It could be seen that the highest was 92 and the lowest score was 46. Besides that, the average score was 78, and it was classified Good (B). From the result of test, there were two students who failed in increasing their vocabulary mastery through storytelling..

\begin{tabular}{|c|c|}
\hline Students & Score \\
\hline 1 & 92 \\
\hline 2 & 92 \\
\hline 3 & 90 \\
\hline 4 & 88 \\
\hline 5 & 86 \\
\hline 6 & 84 \\
\hline 7 & 84 \\
\hline 8 & 84 \\
\hline 9 & 84 \\
\hline 10 & 84 \\
\hline 11 & 84 \\
\hline 12 & 84 \\
\hline 13 & 82 \\
\hline 14 & 82 \\
\hline 15 & 82 \\
\hline 16 & 82 \\
\hline 17 & 82 \\
\hline 18 & 82 \\
\hline 19 & 82 \\
\hline 20 & 82 \\
\hline 21 & 82 \\
\hline 22 & 82 \\
\hline 23 & 82 \\
\hline 24 & 82 \\
\hline 25 & 82 \\
\hline 26 & 82 \\
\hline 27 & 80 \\
\hline 28 & 80 \\
\hline
\end{tabular}

\begin{tabular}{|c|c|}
\hline Students & Score \\
\hline 29 & 80 \\
\hline 30 & 80 \\
\hline 31 & 80 \\
\hline 32 & 80 \\
\hline 33 & 80 \\
\hline 34 & 80 \\
\hline 35 & 78 \\
\hline 36 & 78 \\
\hline 37 & 78 \\
\hline 38 & 78 \\
\hline 39 & 78 \\
\hline 40 & 78 \\
\hline 41 & 78 \\
\hline 42 & 78 \\
\hline 43 & 78 \\
\hline 44 & 78 \\
\hline 45 & 78 \\
\hline 46 & 78 \\
\hline 47 & 78 \\
\hline 48 & 78 \\
\hline 49 & 78 \\
\hline 50 & 78 \\
\hline 51 & 78 \\
\hline 52 & 78 \\
\hline 53 & 76 \\
\hline 54 & 76 \\
\hline 55 & 76 \\
\hline 56 & 76 \\
\hline
\end{tabular}

\begin{tabular}{|c|c|}
\hline Students & Score \\
\hline 57 & 76 \\
\hline 58 & 76 \\
\hline 59 & 76 \\
\hline 60 & 76 \\
\hline 61 & 76 \\
\hline 62 & 76 \\
\hline 63 & 76 \\
\hline 64 & 76 \\
\hline 65 & 76 \\
\hline 66 & 74 \\
\hline 67 & 74 \\
\hline 68 & 74 \\
\hline 69 & 74 \\
\hline 70 & 74 \\
\hline 71 & 74 \\
\hline 72 & 74 \\
\hline 73 & 74 \\
\hline 74 & 68 \\
\hline 75 & 68 \\
\hline 76 & 68 \\
\hline 77 & 68 \\
\hline 78 & 66 \\
\hline 79 & 48 \\
\hline 80 & 46 \\
\hline Average Score & 78 \\
\hline & \\
\hline
\end{tabular}

Table 2 Vocabulary Test 
In spite of the good score, the researcher also classified the score into scoring standard according to Arikunto in Furqon (2013), from the conversion table, we can find that 34 students (43\%) got excellent score (A), 39 students (49\%) got good score (B), 5 students $(6 \%)$ got fair score (C), two students (2\%) got poor score (D), and no students failed in this test.

\begin{tabular}{|c|c|c|c|c|}
\hline Range of Score & Interpretation & Letter Grade & $\begin{array}{c}\text { Number of } \\
\text { Students }\end{array}$ & Percentage \\
\hline $80-100$ & Excellent & A & 34 & 43 \\
\hline $60-79$ & Good & B & 39 & 6 \\
\hline $60-69$ & Fair & C & 5 & 2 \\
\hline $40-59$ & Poor & D & 2 & 0 \\
\hline $0-39$ & Fail & E & 0 & \\
\hline
\end{tabular}

Table 3. The Conversion Table

This research investigated the vocabulary mastery through storytelling to 80 students of Architecture Study Program of Samarinda State Polytechnic. In this research, the students needed telling stories before they had the English vocabulary test. From the test, it could be concluded that the highest score was 92 got by one (1) student while the lowest score was 46 got by one (1) student. Meanwhile, the average score was 78 that classified fair (B). There were two (2) students who got below 50 that classified Fail. The results show that even the students' English mastery were satisfied but the students still need to practice how to tell the story in a good way so that they will master in all aspects.

\section{CONCLUSION}

Based on the result above, the researcher would like to give some suggestions that can give some contributions to the management of Samarinda State Politechnic. It is advised to the English lecturers to ask the students to tell some English stories in front of the class so that the students will get used to talk in front of the public and also to increase their English vocabularies as well as understand the meaning of the stories. 


\section{BIBLIOGRAPHY}

Alterio, M. (2003). Using storytelling to enhance student learning. The Higher Education Academy. Retrieved from http://wwwnew1.heacademy.ac.uk/assets/documents/resources/resourcedatabase/id471_using_story telling_to_enhance_learning.pdf.

Anggriani, D. (2012). Improving Students' Vocabulary Achievement Through Word Walls Strategy, 1-7.

Anisa, I. (2016). The Vocabulary Mastery of the second Semester Students of Widya Dharma University in academic Year 2015/2016. Magistra, (98), 60-70.

Asih, M., \& Nugroho, A. . (2016). Teaching Descriptive Reading Comprehension Using Team Assisted Individualization (TAI) to the Seventh Grade Students. RETAIN, 4(1), 111.

Blachowicz, C. L. Z., Fisher, P. J., \& Watts-taffe, S. (2005). Integrated vocabulary instruction : meeting the needs of diverse learners in grades $\mathrm{K}-5$. Leagning Point Associates, 1.

Boyce, M. (n.d.). Collective centering and collective sense-making in the stories and storytelling of one organization. Organizational Studies, 16(1), 107-138.

Eck, J. (2006). An Analysis of the Effectiveness of storytelling with Adult Learners in Supervisory Management. University of Winconsin-Stout.

Furqon, F. (2013). Correlation Between Students's Vocabulary Mastery and Their Reading Comprehension. Journal of English and Education 2013, 1(1), 68-80, 1(2013), 68-80.

Muijs, D. (2004). Doing Quantitative Research in Education with SPSS. Sage Publication.

Nilawati, S. (2009). The Effectiveness of Teaching Vocabulary by Using Puppet at Elementary School Students( The Case study of the Fourth Graders of SDN Leteh II Rembang in the Academic Year of 2007 / 2008 ).

Setiawan, B. (2010). Improving the Students' Vocabulary Mastery Through Direct Instruction. Universitas Sebelas Maret Surakarta. https://doi.org/10.1017/CBO9781107415324.004

Skhela, K. A. A. (2010). The Effectiveness of Using Storytelling Technique in Enhancing 11. The Islamic University - Gaza.

Taylor, J. M. (2013). Storytelling Engagement in the Classroom: Obervable Behavioural Cues of Children's Story Experiences. The University of Newcastle.

Ur, P. (1996). A course in Language Teaching Practice and Theory. 